\title{
AOR
}

Selected Papers of \#AolR2020:

The $21^{\text {st }}$ Annual Conference of the

Association of Internet Researchers

Virtual Event / 27-31 October 2020

\section{AM THE VIRUS: DIGITAL STORYTELLING AND FICTIONAL TWITTER ACCOUNTS IN THE CORONAVIRUS CRISIS IN SPAIN}

\author{
Antoni Roig \\ Universitat Oberta de Catalunya \\ Sandra Martorell \\ Universitat Politècnica de València
}

The purpose of this work is to understand the role of digital storytelling as a conversation asset regarding social and health emergencies, specifically fictional parody characters in social media, as chroniclers of ongoing crises. We will focus on a strikingly popular phenomenon: the Twitter account @coronavid19, where the virus, presented as a fictional character, offers a humorous chronicle in almost real time through social media, from the early breaking news related to the presence of the virus in the country to the unfolding of an unprecedented social and health crisis. The account got more than 450,000 followers in its first week of existence, coinciding with the first confirmed Covid19 cases in mainland Spain (February 2020) and was widely covered by mainstream media. It currently has more than 860.000 followers, which is way higher than official health and governmental Twitter accounts. This paradigmatic case study has been chosen considering its impact from the early stages of the pandemic, but also its peculiarities as a fictional character and a privileged chronicler in the first person. Through @Coronavid19, the virus becomes a tangible character that details, with elevated doses of sarcasm, the Spanish leg of its so-called 'world tour'. The anonymous user started posting just at the same time of the first cases where detected in mainland Spain and it often mentioned news content in unfolding its real-time narrative. The popularity of @coronavid19 has also led to the appearance of further fictional characters impersonating other diseases or other health-related fictional characters.

Our case analysis is aimed to understand how fictional parody characters are built in discursive and extra-discursive terms, how they interact with followers and how narrative and character traits evolve along the crisis. We also want to observe whether they add nuances to social discussion, reframe news content (emphasizing or downplaying events) and serve as a tool to cope with hard times, fostering collective empowerment, mutual empathy (Caracciolo, 2014; Bal, Brokerhof \& Dolci,

Roig, A. \& Martorell, S. (2020, October). I am the virus: digital storytelling and fictional twitter accounts in the coronavirus crisis in Spain. Paper presented at AolR 2020: The $21^{\text {th }}$ Annual Conference of the Association of Internet Researchers. Virtual Event: AolR. Retrieved from http://spir.aoir.org. 


\section{AOR}

Selected Papers of \#AolR2020:

The $21^{\text {st }}$ Annual Conference of the

Association of Internet Researchers

Virtual Event / 27-31 October 2020

2018) while stressing official recommendations, using irony and mocking irrational behaviour.

We consider storytelling and fiction to be viable tools for social transformation, as alternatives to current and future social challenges through affective attachment to feasible narratives, thus complementing factual scientific projections and models. Storytelling can be used to improve communication of science overcoming the 'narrative deficit' (Veland et al, 2018) making the intangible tangible (through fictional narratives that are strongly rooted in current events). In line with the literature on narratives and sustainability, stories that are seen as close can help to emotionally engage citizens in essential debates regarding how to face global challenges (Moezzi, Janda and Rotmann, 2017). This way, compelling fictional narratives can foster collective action around critical social issues.

We have carried out a participant observation of account activity, thus allowing us to observe playful and non-playful reactions, key mentions and the overall unfolding of the character-based narrative. This was done first through day-to-day observation, daily data extraction through the open-source tool $R$ Studio $(n=954)$ plus occasional extractions from related users. At given times, approximately every two months, we undertook an overall analysis looking for twists and narrative wholeness. We have conducted content analysis to identify different narratives strategies, relation to current events (including those ignored or side-lined by the character), a taxonomy of key topics and significant interactions with other users, be it individuals, other fictional characters or institutions.

Furthermore, we did a semi-structured interview with the user behind @CoronaVid19 in April 2020, respecting anonymity, a key feature of most parody accounts. Eighteen questions were passed to the author -presented as a male-, revolving around four key areas: authorial profile (6 questions), account management (4), narrative style and twists (4), interaction with other accounts (4). These answers allowed us to complement and to get a better overview and to take the case study further.

A distinctive feature of such narratives emerging during an ongoing crisis is that they can't be planned beforehand and don't have a predictable course, thus forcing characters to react to breaking events and the evolving mood of their followers. In our analysis, we have observed that the Coronavirus threat was initially seen as 'distant' by the population living far from the main focus of infection. Subsequently, danger was seen as tangible and close, and feelings of disbelief gave way to

Roig, A. \& Martorell, S. (2020, October). I am the virus: digital storytelling and fictional twitter accounts in the coronavirus crisis in Spain. Paper presented at AolR 2020: The $21^{\text {th }}$ Annual Conference of the Association of Internet Researchers. Virtual Event: AolR. Retrieved from http://spir.aoir.org. 


\section{AOR}

Selected Papers of \#AolR2020:

The $21^{\text {st }}$ Annual Conference of the

Association of Internet Researchers

Virtual Event / 27-31 October 2020

paranoia and fear. Weeks later, a pandemic was declared and the rate of infection and deaths were alarmingly on the rise, leading to the declaration of a State of Alarm and confinement. All these events influenced the unfolding narrative of @CoronaVid19 account, evolving towards a more humanized character, using a more observational and lighter humour. Attempting to find the right tone was not easy amid a global drama surrounded by a feeling of fear and uncertainty. Uncertainty that was a seed for rumours, contradictory statements, fake news and conspiracy theories.

Different research actions have been undertaken so far, and we summarize some of our key findings as follows: (1) Fictional characters like @Coronavid19 succeed in counterbalancing collective fear by mocking irrational reactions, or defusing fear making the threat tangible, humanizing it and showing it as vulnerable; (2) The author was forced to make an ethical stand once the account proved to be successful and the crisis more serious and unpredictable than expected, softening the character's edges towards a more everyday humour with a political and social edge and stressing safety measures; (3) This process means side-lining some of the bleakest implications of the pandemic (death rates, psychological effects and economic crisis); (4) @Coronavid19 works as a character-driven narrative, with a transformation arc in an otherwise unpredictable plot; (5) followers, even those who have suffered from Covid-19, react playfully and fondly to the character-, except when political polarization takes over.

\section{References}

Bal, M., Brokerhof, I. \& Dóci, E. (2018). How does fiction inform working lives? An exploration of the roles of empathy and social sustainability. Working paper.

Bore, I. L. K. \& Hickman, J. (2013). Continuing The West Wing in 140 characters or less: Improvised simulation on Twitter. The Journal of Fandom Studies, 1(2), 219-238.

Caracciolo, M. (2014). Beyond other minds: fictional characters, mental simulation, and" unnatural" experiences. Journal of Narrative Theory, 44(1), 29-53. 


\section{AOR}

Selected Papers of \#AoIR2020: The $21^{\text {st }}$ Annual Conference of the Association of Internet Researchers Virtual Event / 27-31 October 2020

Highfield, T. (2016). News via Voldemort: Parody accounts in topical discussions on Twitter. New Media \& Society, 18(9), 2028-2045.

Moezzi, M., Janda, K. B. \& Rotmann, S. (2017). Using stories, narratives, and storytelling in energy and climate change research. Energy Research \& Social Science, 31, 1-10.

Pak, C. (2015). 'The goal of Martian economics is not "sustainable development" but a sustainable prosperity for its entire biosphere': science fiction and the sustainability debate. Green Letters, 19(1), 36-49.

Veland, S., Scoville-Simonds, M., Gram-Hanssen, I., Schorre, A. K., El Khoury, A., Nordbø, M. J. \& Bjørkan, M. (2018). Narrative matters for sustainability: the transformative role of storytelling in realizing $1.5 \mathrm{C}$ futures. Current Opinion in Environmental Sustainability, 31, 41-47.

Weber, M. \& Driscoll, B. (2019). Playful Twitter accounts and the socialisation of literary institutions. First Monday, 24(3).

Yusoff, K. \& Gabrys, J. (2011). Climate change and the imagination. Wiley Interdisciplinary Reviews: Climate Change, 2(4), 516-534.

Roig, A. \& Martorell, S. (2020, October). I am the virus: digital storytelling and fictional twitter accounts in the coronavirus crisis in Spain. Paper presented at AolR 2020: The $21^{\text {th }}$ Annual Conference of the Association of Internet Researchers. Virtual Event: AolR. Retrieved from http://spir.aoir.org. 